\title{
Effect of royal jelly on bovine sperm characteristics during post-thaw incubation in vitro
}

\author{
Abd-Allah, Saber Mohammed \\ Department of Theriogenology, Faculty of Veterinary Medicine, Beni-Suef University, 62511 Beni-Suef, Egypt. \\ Tel.: +20114822689, Fax.:+20822327982. Email: sma_elhadidy@yahoo.com
}

\begin{abstract}
Abd-Allah, S.M.: Effect of royal jelly on bovine sperm characteristics during post-thaw incubation in vitro. Rev. vet. 21: 2, 81-85, 2010. Cryopreserved bovine semen is generally considered to have lower fertility compared to fresh semen. The reduction arises from both a lower post-thaw viability and a possible sublethal dysfunction of the surviving sperm population. The present study was conducted to observe the effect of royal jelly (RJ) on motility, viability and acrosome integrity of spermatozoa during post-thaw incubation. Frozen-thawed semen samples were washed and incubated at $37^{\circ} \mathrm{C}$ in Tris buffer containing $0.1,0.2,0.3,0.4$, $0.5 \% \mathrm{RJ}$ or none (control). Sperm motility, viability and acrosomal integrity were assessed at $0,0.5,1,1.5$ and $2 \mathrm{~h}$. The percentages of sperm motility, viability and intact acrosome were higher in Tris buffer containing $0.4 \%$ RJ compared to control ( $p<0.05$ ). After $2 \mathrm{~h}$ of incubation the percentages of motility, viability and intact acrosome of spermatozoa, respectively, were $52.3 ; 52.5$ and $19.8 \%$ in $0.4 \%$ RJ containing buffer. Results indicate that the addition of $0.4 \% \mathrm{RJ}$ in the incubation media was able to maintain better quality and longevity of spermatozoa. Royal jelly may be used as a semen extender to improve sperm quality and fertility.
\end{abstract}

Key words: cattle, sperm, royal jelly, longevity, viability.

\section{Resumen}

Abd-Allah, S.M.: Efectos de la incubación in vitro con jalea real sobre las características del semen bovino descongelado. Rev. vet. 21: 2, 81-85, 2010. El semen bovino criopreservado generalmente es considerado de menor poder fertilizante comparado con el semen fresco. Tal reducción abarca tanto una más baja viabilidad post-descongelado como una posible disfunción subletal de la población de espermatozoides sobrevivientes. El presente estudio fue realizado para determinar el efecto de la jalea real (JR) sobre la motilidad, viabilidad e integridad acrosomal de espermatozoides durante la etapa de incubación post-descongelado. Las muestras de semen congelado-descongelado se lavaron e incubaron a $37^{\circ} \mathrm{C}$ en buffer Tris conteniendo JR en proporción de 0,$1 ; 0,2 ; 0,3 ; 0,4 ; 0,5 \%$ o ninguna (control). La motilidad y la viabilidad espermáticas, así como la integridad acrosomal, fueron evaluadas a las $0 ; 0,5 ; 1$; 1,5 y $2 \mathrm{~h}$. Comparados con los controles, los porcentajes de motilidad, viabilidad e integridad acrosomal fueron más altos en los espermatozoides incubados en Tris conteniendo $0,4 \%$ de JR $(\mathrm{p}<0,05)$. Después de $2 \mathrm{~h}$ de incubación, los porcentajes de motilidad, viabilidad e integridad acrosomal de los espermatozoides fueron respectivamente de 52,3; 52,5 y $19,8 \%$ en el buffer que contenía JR al 0,4\%. Los resultados indican que la adición de $0,4 \%$ de JR en los medios de incubación fue capaz de mantener la buena calidad y longevidad de los espermatozoides. La jalea real puede ser usada como aditivo seminal para mejorar la viabilidad y fertilidad de los espermatozoides.

Palabras clave: bovino, semen, jalea real, longevidad, viabilidad.

\section{INTRODUCTION}

Royal jelly is secreted by the hypopharyngeal glands of worker bees to feed young larvae and the adult queen bee. On dry matter basis, royal jelly contains considerable amounts of proteins, amino acids including 8 essential amino acids particularly rich in cystine, lysine and arginine, hormone rich substance

Recibido: 27 octubre 2010 / Aceptado: 22 noviembre 2010 (testosterone and insulin like growth factor-1, IGF-I), lipid, and sugars. Royal jelly also contains enzymes antibiotic components, vitamin A, B (pantothenic acid, has antioxidant effect), C, D, and E. Mineral salts are in descending order: $\mathrm{K}, \mathrm{Ca}, \mathrm{Na}, \mathrm{Zn}, \mathrm{Fe}, \mathrm{Cu}$, and $\mathrm{Mn}$. It also has an abundance of nucleic acid-DNA and RNA. Also it contains sterols, phosphorous compounds and acetylcholine, which is needed to transmit nerve messages from cell to cell ${ }^{12,13}$. 
The duration of motility and other sperm characteristics during post-thawing incubation is an indication of the usability of the semen ${ }^{16}$. The maintenance of higher motility in sperm during post-thawing incubation reflects a greater likelihood of their survival in the female genital tract to undergo capacitation and fertilize ova ${ }^{8}$.

The reasons for the loss of fertility are various such as factors affecting the proportion of survivors (e.g., cold shock susceptibility, cooling rate, diluent composition, and osmotic stress) and factors influence functional status of survivors of sperm cells (e.g., membrane stability, oxidative damage, membrane receptor integrity, nuclear structure) ${ }^{1}$.

Spermatozoa, unlike other cells, are unique in structure, function, and very susceptible to damage by reactive oxygen species $(\mathrm{ROS})^{2}$. It is worth mentioning that increased amount of ROS during freeze-thawed semen can be responsible for mitochondrial dysfunction, DNA, RNA and protein damage and lipid peroxidation ${ }^{2}$. In effect, the membrane of mitochondria is highly susceptible to lipid peroxidative damage which may therefore result in impaired control of intracellular $\mathrm{Ca}^{2+}$ (as the mitochondria has a high $\mathrm{Ca}^{2+}$ sequestering ability), inhibition of respiration and depletion of ATP ${ }^{11}$. Lipid peroxidation has also been shown to induce irreversible loss of sperm motility, leakage of intracellular enzymes, damage to the chromatin and decreased capacity of sperm-oocyte plasma membrane fusion.

Functionally active spermatozoa membrane and the mitochondrial activity are required for spermatozoa metabolism ${ }^{6}$. However, spermatozoa motility reflects their mitochondrial function indirectly. The spermatozoa motility, viability and acrosomal integrity of sperm cells correlate positively with fertility of bovine bulls ${ }^{10}$.

No report is available on elucidation of the role of royal jelly on spermatozoa function parameters in bovine. Thus, the aim of the present study was to observe the effect of addition of different concentrations of royal jelly on motion characteristics and acrosomal integrity of bovine spermatozoa during post-thawing incubation.

\section{MATERIAL AND METHODS}

All materials were purchased from Sigma Chemical Company (St Louis, Missouri) unless otherwise indicated.

Royal jelly. Pure royal jelly capsules were used in this study (Pharco Pharmaceuticals Co., Egypt). Each capsule $(1000 \mathrm{mg})$ was dissolved in $10 \mathrm{ml}$ double distilled water to get concentration of $100 \mathrm{mg} \mathrm{ml}^{-1}$.

Frozen semen samples. Frozen semen straws of five Friesian bulls (4 years age) were thawed by immersion in $37^{\circ} \mathrm{C}$ for $45 \mathrm{~s}$ and the semen was pooled and were mixed well in Tris buffer $(0.25 \mathrm{M}$ Tris, $80 \mathrm{mM}$ citric acid, $69 \mathrm{mM}$ fructose and antibiotics). Frozen semen showing at least $54.3 \%$ motility, $55.3 \%$ live spermatozoa and $15.2 \%$ acrosomal damage was centrifuged $(800 \times \mathrm{g})$ at $37^{\circ} \mathrm{C}$ for $5 \mathrm{~min}$, the sperm pellet was washed two or three times with Tris-buffer $(\mathrm{pH}$ 7.4), re-suspended in Tris-buffer and divided into six equal portion in six test tubes. To one tube (control) only Tris-buffer was added and the remaining five tubes (experimental portions) were subjected to royal jelly treatment $(0.1,0.2,0.3,0.4,0.5 \%)$. All sperm suspensions were incubated at $37^{\circ} \mathrm{C}$ for various periods.

Assessment of spermatozoa functional parameters. Every $30 \mathrm{~min}$, the progressive motility, viability and acrosomal integrity of thawed spermatozoa after washed in Tris-extender plus royal jelly was assessed 4 times every $30 \mathrm{~min}$ interval along incubation period $(2 \mathrm{~h})^{4}$.

Individual motility. One drop of the spermatozoaTris-royal jelly extender mixture was placed on a prewarmed, clean microscopic slide $\left(37^{\circ} \mathrm{C}\right)$ and covered with a pre-warmed $\left(35^{\circ} \mathrm{C}\right)$, clean cover slip. A video recording was made using light microscope (Olympus BX60) at approximately $400 \times$ with an attached video camera, a video monitor and a video machine. A minimum of 500 spermatozoa from at least two different drops was analyzed for each sample ${ }^{21}$.

Sperm Viability. Sperm viability (at hour 0 and 2) was determined by preparing an eosin-nigrosin smear $\left(37^{\circ} \mathrm{C}\right)$ and assessing at least 100 sperms under brightfield microscopy (Olympus BX60) at approximately $1000 \times{ }^{4}$.

Acrosomal integrity. Treated frozen semen samples with royal jelly were washed twice by centrifugation $600 \times \mathrm{g}$ using sodium citrate buffer. The supernatant fluid was discarded at every time and the pellet was covered by a suitable amount of buffer. Dry smears were made from one drop of the washed diluted semen with one drop of Wells and Awa stain ${ }^{20}$. The slides were observed under a light microscope (Olympus BX60) at approximately $1000 \times$ and assessed for the number of sperm that had undergone acrosome reaction. A total of 100 cells were counted from each smear, having 4 smears analyzed from frozen-thawed semen samples ${ }^{19}$.

Statistical analysis. One way variance analysis' were used to evaluate the significance levels between the parameters studied. The critical differences of three factors: A (incubation period), B (royal jelly treatments) and A x B interactions were used to find the level of significance. A $p$ value of 0.05 was selected as a criterion for statistically significant differences.

\section{RESULTS}

The results of the present study showed that royal jelly can enhance and maintain bovine sperm function parameters in a dose and incubation time's dependent manner (Tables 1, 2, 3).

Results of experiment showed that the percentages of sperm function parameters were improved with an increase of royal jelly in Tris extender from 0.1 to $0.4 \%$ 
Table 1. Progressive motility of bovine spermatozoa thawed and held in Tris-royal jelly extender $(0.0-0.5 \%)$ over $2 \mathrm{~h}$ incubation period $(\overline{\mathrm{x}} \pm \mathrm{SE})$

\begin{tabular}{|c|c|c|c|c|c|c|c|}
\hline \multirow{2}{*}{$\begin{array}{l}\text { IP } \\
(\mathrm{h})\end{array}$} & \multicolumn{7}{|c|}{ royal jelly concentration } \\
\hline & $\begin{array}{c}\text { zero \% } \\
\text { (control) }\end{array}$ & $0.1 \%$ & $0.2 \%$ & $0.3 \%$ & $0.4 \%$ & $0.5 \%$ & CFM \\
\hline 0 & $\begin{array}{c}54.3 \\
\pm 0.2^{\text {(e) }}\end{array}$ & $\begin{array}{c}54.5 \\
\pm 0.2^{(\mathrm{e})}\end{array}$ & $\begin{array}{c}54.4 \\
\pm 0.2^{\text {(e) }}\end{array}$ & $\begin{array}{c}54.3 \\
\pm 0.2^{(\mathrm{e})}\end{array}$ & $\begin{array}{c}54.5 \\
\pm 0.2^{(\mathrm{e})}\end{array}$ & $\begin{array}{c}54.4 \\
\pm 0.2^{\text {(e) }}\end{array}$ & $\begin{array}{c}54.4 \\
\pm 0.04^{\text {(B }}\end{array}$ \\
\hline 0.5 & $\begin{array}{c}32.4 \\
\pm 0.16^{(\mathrm{a})}\end{array}$ & $\begin{array}{c}45.3 \\
\pm 0.15^{(\mathrm{b})}\end{array}$ & $\begin{array}{c}47.4 \\
\pm 0.15^{(\mathrm{c})}\end{array}$ & $\begin{array}{c}50.1 \\
\pm 0.16^{(\mathrm{d})}\end{array}$ & $\begin{array}{c}53.3 \\
\pm 0.15^{(\mathrm{f})}\end{array}$ & $\begin{array}{c}53.3 \\
\pm 0.26^{(f)}\end{array}$ & $\begin{array}{c}46.9 \\
\pm 3.1^{(\mathrm{A})}\end{array}$ \\
\hline 1 & $\begin{array}{c}26.7 \\
\pm 0.15^{(\mathrm{b})}\end{array}$ & $\begin{array}{c}43.6 \\
\pm 0.16^{(\mathrm{a})}\end{array}$ & $\begin{array}{c}45.3 \\
\pm 0.26^{(\mathrm{d})}\end{array}$ & $\begin{array}{c}47.3 \\
\pm 0.15^{(\mathrm{c})}\end{array}$ & $\begin{array}{c}52.2 \\
\pm 0.2^{(\mathfrak{f})}\end{array}$ & $\begin{array}{c}52.1 \\
\pm 0.2^{(\mathrm{f})}\end{array}$ & $\begin{array}{r}44.5 \\
\pm 3.8^{(\mathrm{A})}\end{array}$ \\
\hline 1.5 & $\begin{array}{c}19.6 \\
\pm 0.16^{(\mathrm{c})}\end{array}$ & $\begin{array}{c}35.3 \\
\pm 0.14^{(\mathrm{d})}\end{array}$ & $\begin{array}{c}39.0 \\
\pm 0.25^{(\mathrm{a})}\end{array}$ & $\begin{array}{c}44.6 \\
\pm 0.16^{(f)}\end{array}$ & $\begin{array}{c}51.5 \\
\pm 0.16^{(\mathrm{b})}\end{array}$ & $\begin{array}{c}51.4 \\
\pm 0.2^{(\text {b) }}\end{array}$ & $\begin{array}{c}40.2 \\
\pm 4.9^{(\mathrm{C})}\end{array}$ \\
\hline 2 & $\begin{array}{c}16.5 \\
\pm 0.16^{(\mathrm{f})}\end{array}$ & $\begin{array}{c}31.6 \\
\pm 0.16^{(\mathrm{c})}\end{array}$ & $\begin{array}{c}34.9 \\
\pm 0.18^{(\mathrm{b})}\end{array}$ & $\begin{array}{c}39.5 \\
\pm 0.16^{(\mathrm{a})}\end{array}$ & $\begin{array}{c}50.1 \\
\pm 0.16^{(\mathrm{d})}\end{array}$ & $\begin{array}{c}50.0 \\
\pm 0.16^{(\mathrm{d})}\end{array}$ & $\begin{array}{r}37.1 \\
\pm 5.1^{(\mathrm{D})}\end{array}$ \\
\hline CFM & $\begin{array}{c}29.9 \\
\pm 6.6^{(\mathrm{B})} \\
\end{array}$ & $\begin{array}{c}42.1 \\
\pm 4.0^{(\mathrm{C})} \\
\end{array}$ & $\begin{array}{c}44.2 \\
\pm 3.3^{(\mathrm{D})} \\
\end{array}$ & $\begin{array}{c}47.2 \\
\pm 2.5^{(\mathrm{E})} \\
\end{array}$ & $\begin{array}{c}52.3 \\
\pm 0,7^{(\mathrm{A})} \\
\end{array}$ & $\begin{array}{c}52.5 \\
\pm 0.7^{(\mathrm{A})} \\
\end{array}$ & \\
\hline
\end{tabular}

IP: incubation period, CFM: combination factor means. Each value represents $\overline{\mathrm{x}} \pm \mathrm{SE}$ of fifteen observations of five bulls. Values with the different superscript $(\mathrm{a}-\mathrm{b}-\mathrm{c}-\mathrm{d}-\mathrm{e}-\mathrm{f}, \mathrm{A}-\mathrm{B}-\mathrm{C}-\mathrm{D}-\mathrm{E})$ in the same row or column were significantly different at $\mathrm{p}<0.05$.

Table 2. Viability of bovine spermatozoa thawed and held in Tris-royal jelly extender $(0.0-0.5 \%)$ over $2 \mathrm{~h}$ incubation period $(\overline{\mathrm{x}} \pm \mathrm{SE})$.

\begin{tabular}{|c|c|c|c|c|c|c|c|}
\hline \multirow{2}{*}{$\begin{array}{l}\text { IP } \\
\text { (h) }\end{array}$} & \multicolumn{7}{|c|}{ royal jelly concentration } \\
\hline & $\begin{array}{c}\text { zero \% } \\
\text { (control) }\end{array}$ & $0.1 \%$ & $0.2 \%$ & $0.3 \%$ & $0.4 \%$ & $0.5 \%$ & CFM \\
\hline 0 & $\begin{array}{c}55.3 \\
\pm 0.2^{\text {(e) }}\end{array}$ & $\begin{array}{c}55.5 \\
\pm 0.2^{(\mathrm{e})}\end{array}$ & $\begin{array}{c}55.4 \\
\pm 0.2^{(\mathrm{e})}\end{array}$ & $\begin{array}{c}55.3 \\
\pm 0.2^{(\mathrm{e})}\end{array}$ & $\begin{array}{c}55.5 \\
\pm 0.2^{(\mathrm{e})}\end{array}$ & $\begin{array}{c}55.4 \\
\pm 0.2^{(\mathrm{e})}\end{array}$ & $\begin{array}{c}55.4 \\
\pm 0.02^{\text {(B }}\end{array}$ \\
\hline 0.5 & $\begin{array}{c}35.4 \\
\pm 0.16^{(a)}\end{array}$ & $\begin{array}{c}47.3 \\
\pm 0.15^{(\mathrm{b})}\end{array}$ & $\begin{array}{c}48.4 \\
\pm 0.15^{(\mathrm{c})}\end{array}$ & $\begin{array}{c}51.1 \\
\pm 0.16^{(\mathrm{d})}\end{array}$ & $\begin{array}{c}54.3 \\
\pm 0.15^{(\mathrm{f})}\end{array}$ & $\begin{array}{c}54.3 \\
\pm 0.26^{(f)}\end{array}$ & $\begin{aligned} & 48.5 \\
\pm & 2.8^{(\mathrm{A})}\end{aligned}$ \\
\hline 1 & $\begin{array}{c}29.7 \\
\pm 0.15^{(\mathrm{b})}\end{array}$ & $\begin{array}{c}46.6 \\
\pm 0.16^{(a)}\end{array}$ & $\begin{array}{c}46.3 \\
\pm 0.26^{(\mathrm{d})}\end{array}$ & $\begin{array}{c}48.3 \\
\pm 0.15^{(\mathrm{c})}\end{array}$ & $\begin{array}{c}52.2 \\
\pm 0.2^{(\mathrm{f})}\end{array}$ & $\begin{array}{c}52.1 \\
\pm 0.2^{(\mathrm{f})}\end{array}$ & $\begin{array}{c}45.8 \\
\pm 3.4^{(\mathrm{A})}\end{array}$ \\
\hline 1.5 & $\begin{array}{c}21.6 \\
\pm 0.16^{(\mathrm{c})}\end{array}$ & $\begin{array}{c}37.3 \\
\pm 0.14^{(\mathrm{d})}\end{array}$ & $\begin{array}{c}40.0 \\
\pm 0.25^{(\mathrm{a})}\end{array}$ & $\begin{array}{c}45.6 \\
\pm 0.16^{(\mathrm{f})}\end{array}$ & $\begin{array}{c}50.5 \\
\pm 0.16^{(\mathrm{b})}\end{array}$ & $\begin{array}{c}50.4 \\
\pm 0.2^{\text {(b) }}\end{array}$ & $\begin{array}{c}40.9 \\
\pm 4.4^{\mathrm{C})}\end{array}$ \\
\hline 2 & $\begin{array}{c}18.5 \\
\pm 0.16^{(\mathrm{f})}\end{array}$ & $\begin{array}{c}32.6 \\
\pm 0.16^{(\mathrm{c})}\end{array}$ & $\begin{array}{c}36.9 \\
\pm 0.18^{(b)}\end{array}$ & $\begin{array}{c}40.5 \\
\pm 0.16^{(\mathrm{a})}\end{array}$ & $\begin{array}{c}50.1 \\
\pm 0.16^{(\mathrm{d})}\end{array}$ & $\begin{array}{c}50.0 \\
\pm 0.16^{(\mathrm{d})}\end{array}$ & $\begin{array}{c}38.1 \\
\pm 4.8^{(\mathrm{D})}\end{array}$ \\
\hline CFM & $\begin{array}{c}32.1 \\
\pm 6.5^{\text {(B) }} \\
\end{array}$ & $\begin{array}{c}43.8 \\
\pm 4.0^{\mathrm{C})} \\
\end{array}$ & $\begin{array}{c}45.4 \\
\pm 3.2^{\text {(D) }} \\
\end{array}$ & $\begin{array}{c}48.1 \\
\pm 2.5^{(\mathrm{E})} \\
\end{array}$ & $\begin{array}{c}52.5 \\
\pm 1.0^{(\mathrm{A})} \\
\end{array}$ & $\begin{array}{c}52.4 \\
\pm 1.0^{(\mathrm{A})} \\
\end{array}$ & \\
\hline
\end{tabular}

IP: incubation period, CFM: combination factor means. Each value represents $\overline{\mathrm{x}} \pm \mathrm{SE}$ of fifteen observations of five bulls. Values with the different superscript $(\mathrm{a}-\mathrm{b}-\mathrm{c}-\mathrm{d}-\mathrm{e}-\mathrm{f}, \mathrm{A}-\mathrm{B}-\mathrm{C}-\mathrm{D}-\mathrm{E})$ in the same row or column were significantly different at $\mathrm{p}<0.05$.

Table 3. Acrosomal defects of bovine spermatozoa thawed and held in Tris-royal jelly extender $(0.0-0.5 \%)$ over $2 \mathrm{~h}$ incubation period $(\overline{\mathrm{x}} \pm \mathrm{SE})$.

\begin{tabular}{|c|c|c|c|c|c|c|c|}
\hline \multirow{2}{*}{$\begin{array}{l}\text { IP } \\
\text { (h) }\end{array}$} & \multicolumn{7}{|c|}{ royal jelly concentration } \\
\hline & $\begin{array}{c}\text { zero \% } \\
\text { (control) }\end{array}$ & $0.1 \%$ & $0.2 \%$ & $0.3 \%$ & $0.4 \%$ & $0.5 \%$ & CFM \\
\hline 0 & $\begin{array}{c}15.2 \\
\pm 0.16^{(\mathrm{e})}\end{array}$ & $\begin{array}{c}15.4 \\
\pm 0.13^{(\mathrm{e})}\end{array}$ & $\begin{array}{c}15.5 \\
\pm 0.1^{(\mathrm{e})}\end{array}$ & $\begin{array}{c}15.4 \\
\pm 0.24^{(\mathrm{e})}\end{array}$ & $\begin{array}{c}15.2 \\
\pm 0.24^{(\mathrm{e})}\end{array}$ & $\begin{array}{c}15.2 \\
\pm 0.24^{(\mathrm{e})}\end{array}$ & $\begin{array}{c}15.4 \\
\pm 0.1^{\text {(B }}\end{array}$ \\
\hline 0.5 & $\begin{array}{c}25.7 \\
\pm 0.26^{(\mathrm{a})}\end{array}$ & $\begin{array}{c}22 \\
\pm 0.16^{(\mathrm{b})}\end{array}$ & $\begin{array}{c}21.2 \\
\pm 0.21^{(\mathrm{c})}\end{array}$ & $\begin{array}{c}17.9 \\
\pm 0.16^{(\mathrm{d})}\end{array}$ & $\begin{array}{c}17.4 \\
\pm 0.18^{(\mathrm{f})}\end{array}$ & $\begin{array}{c}17.4 \\
\pm 0.18^{(\mathrm{f})}\end{array}$ & $\begin{array}{r}20.2 \\
\pm 1.3^{\text {(A }}\end{array}$ \\
\hline 1 & $\begin{array}{c}30.6 \\
\pm 0.16^{(\mathrm{b})}\end{array}$ & $\begin{array}{c}27.7 \\
\pm 0.15^{(\mathrm{a})}\end{array}$ & $\begin{array}{c}25.0 \\
\pm 0.21^{(\mathrm{d})}\end{array}$ & $\begin{array}{c}22.0 \\
\pm 0.21^{(\mathrm{c})}\end{array}$ & $\begin{array}{c}19.5 \\
\pm 0.16^{(\mathrm{f})}\end{array}$ & $\begin{array}{c}19.5 \\
\pm 0.16^{(\mathrm{f})}\end{array}$ & $\begin{array}{r}24.0 \\
\pm 1.8^{(\mathrm{A}}\end{array}$ \\
\hline 1.5 & $\begin{array}{c}34.5 \\
\pm 0.2^{(\mathrm{c})}\end{array}$ & $\begin{array}{c}28.7 \\
\pm 0.15^{(\mathrm{d})}\end{array}$ & $\begin{array}{c}27.1 \\
\pm 0.18^{(\mathrm{a})}\end{array}$ & $\begin{array}{c}26.3 \\
\pm 0.15^{(\mathrm{f})}\end{array}$ & $\begin{array}{c}22.7 \\
\pm 0.15^{(\mathrm{a})}\end{array}$ & $\begin{array}{c}22.7 \\
\pm 0.15^{\text {(a) }}\end{array}$ & $\begin{array}{r}22.0 \\
\pm 1.7^{\mathrm{C}}\end{array}$ \\
\hline 2 & $\begin{array}{c}40.6 \\
\pm 0.16^{(\mathrm{f})}\end{array}$ & $\begin{array}{c}31.6 \\
\pm 0.16^{(\mathrm{c})}\end{array}$ & $\begin{array}{c}32.4 \\
\pm 0.16^{\text {(b) }}\end{array}$ & $\begin{array}{c}28.7 \\
\pm 0.15^{(\mathrm{a})}\end{array}$ & $\begin{aligned} & 24.6 \\
\pm & 0.16^{(\mathrm{d})}\end{aligned}$ & $\begin{aligned} & 24.5 \\
\pm & 0.16^{\text {(d }}\end{aligned}$ & $\begin{array}{r}30.4 \\
\pm 2.4^{(\mathrm{D}}\end{array}$ \\
\hline CFM & $\begin{array}{c}29.4 \\
\pm 4.2^{\text {(B) }}\end{array}$ & $\begin{array}{c}25.2 \\
\pm 2.8^{\mathrm{C})}\end{array}$ & $\begin{array}{c}24.3 \\
\pm 2.7^{(\mathrm{D})}\end{array}$ & $\begin{array}{c}22.0 \\
\pm 2.5^{(\mathrm{E})}\end{array}$ & $\begin{array}{l}19.8 \\
\pm 1.7^{(\mathrm{A})}\end{array}$ & $\begin{array}{c}19.8 \\
\pm 1.7^{(\mathrm{A})}\end{array}$ & \\
\hline
\end{tabular}

IP: incubation period, CFM: combination factor means. Each value represents $\overline{\mathrm{x}} \pm \mathrm{SE}$ of fifteen observations of five bulls. Values with the different superscript $(\mathrm{a}-\mathrm{b}-\mathrm{c}-\mathrm{d}-\mathrm{e}-\mathrm{f}, \mathrm{A}-\mathrm{B}-\mathrm{C}-\mathrm{D}-\mathrm{E})$ in the same row or column were significantly different at $\mathrm{p}<0.05$. 
$(\mathrm{p}<0.05)$. Statistical analysis of sperm motility and viability (Tables 1,2 ) showed that the best result (significant higher $\mathrm{p}<0.05$ ) occurred with a royal jelly doses of $0.4 \%$ and $0.5 \%$ especially at 0.5 and $1 \mathrm{~h}$ incubation periods than that of control although the values in both concentrations of royal jelly $(0.4,0.5 \%)$ were nearly similar.

Over a period of $2 \mathrm{~h}$ incubation, up to one-half of sperm in each sample were motile, live and intact on using Tris $-0.4 \%$ royal jelly extender (Tables $1,2,3$ ). Corresponding to incubation period, $\%$ motility, viability and acrosomal integrity of control semen samples dropped $(\mathrm{p} \leq 0.05)$ from hour 0 to hour 2 (Tables 1 , $2,3)$. Royal jelly had significant $(p<0.05)$ effect on acrosomal integrity during the 120 min study period. In addition, acrosomal integrity were significantly $(\mathrm{p}<$ 0.05 ) higher in $0.4 \%$ royal jelly group at $30 \mathrm{~min}$ and 60 min of incubation than control (Table 3).

Statistical analysis showed significant interaction incubation periods $\mathrm{x}$ treatments. Thus, increase or decrease in motility (\%) and viability (\%) with different treatments is affected by increase or decrease the incubation periods or vice versa.

\section{DISCUSSION}

Results of experiment showed that the percentages of sperm function parameters were improved with an increase of RJ in Tris extender from 0.1 to $0.4 \%$. The sperm function parameters were significantly ( $p$ $<0.05$ ) higher at $0.4 \% \mathrm{RJ}$ as compared to the control. Over a period of $120 \mathrm{~min}$ of incubation, up to one-half of sperm in each sample were motile, live and intact on using Tris $-0.4 \%$ RJ extender. This may be attributed to RJ may have reduced the exposure of spermatozoa to oxidative stress at or just after the thawing, by removing excess extracellular ROS present in the semen medium as its composition is highly containing pantothenic acid which have antioxidant effect ${ }^{12}$.

It was suggested that RJ might enhance motility through partial capacitation of sperm cells as its composition is highly containing calcium ions ${ }^{13}$. It was reported that $\mathrm{RJ}$ might maintain the acrosomal integrity as its composition is highly variable containing hormones which decrease oxygen radicals and therefore reducing the number of molecules needed to be scavenged by the superoxide dismutase enzyme which were present normal in seminal plasma to counteract the effects of ROS on lipid peroxidation and prevent spermatozoal damage ${ }^{9}$.

Fructose uptake is not consistent during the period of incubation. Fructose uptake may be increased within $0.5-1 \mathrm{~h}$ of incubation. Then the fructose uptake may be slowed between $1.5-2 \mathrm{~h}$ might be to compensate for the high intake during the first $0.5-1 \mathrm{~h}$. Motility of spermatozoa was related to the rate of sugar utilization in the seminal plasma ${ }^{3}$.

The bovine spermatozoal motility characteristics decline with incubation time. In the present study, the percentage of motile spermatozoa declined significantly during incubation. This may be due to the inability of spermatozoa to generate ATP through mitochondrial respiration as a consequence of mitochondrial aging 5,18 or toxic effect of dead sperm associated with the liberation of amino oxidase activity ${ }^{17}$. I was observed that under aerobic condition during incubation, spermatozoal velocities did not change ${ }^{14}$. In the present study, the aerobic conditions were maintained as sample was withdrawn at an hourly interval during post-thawing incubation. The present finding was in agreement to these reports as the percentage of ram spermatozoa with normal acrosome decreased significantly during incubation ${ }^{15}$.

This effect could be attributed to the RJ contain vitamin $C$, vitamin $E$ and arginine. Vitamin $E$ and $C$ is a well-documented antioxidant and has been shown to inhibit free-radical induced damage to sensitive cell membranes of the testis and reduced lipid peroxidation in tissue estimation by malodialdehyde, so vitamin $\mathrm{E}$ and $\mathrm{C}$ significantly decreased malodialdehyde, and increased in glutathione level ${ }^{7}$. A positive effect of IGFI on functional membrane integrity further suggests the role of RJ on spermatozoa membrane stability.

In conclusion, the study indicated that addition of RJ had significant effect on spermatozoa survivability and acrosomal integrity during post-thawing incubation. The survivability and acrosomal integrity of spermatozoa were better when thawed semen were washed with Tris $-0.4 \% \mathrm{RJ}$ extender and this additive can be used for increasing the possibility of collision between spermatozoa and ova during insemination. Supplementing the frozen-thawed semen samples with RJ could, therefore, be of clinical importance for extending the time of spermatozoa survivability and longevity during artificial insemination, in vitro fertilization, and intrauterine insemination.

\section{REFERENCES}

1. Aitken RJ. 1994. Pathophysiology of human spermatozoa. Curr Opin Obstet Gynecol 6: 128-135.

2. Alvarez JG, Storey BT. 1989. Role of glutathione peroxidase in protecting mammalian spermatozoa from loss of motility caused by spontaneous lipid peroxidation. Gamete Res 23: 77-90.

3. Biswas S, Ferguson KM, Stedronska J. 1987. Fructose and hormone levels in semen; their correlations with sperm counts and motility. Fertil Steril 30: 200-204.

4. Blom E. 1950. The evaluation of bull semen with special reference to its use in artificial insemination. Anim Breed Abstr 19: 648.

5. Cummins M, Jequier AM, Kan R. 1994. Molecular biology of the human male fertility: links with ageing, mitochondrial genetics and oxidative stress. Mol Reprod Dev 37: 345-362.

6. De Lamirande E, Gagnon C. 1992. Reactive oxygen species and human spermatozoa. I. Effects on the motility of 
intact spermatozoa and on sperm axonemes. $J$ Androl 13: 368-378.

7. Ebisch IM, Pierik FH, Jong FH, Thomas CM, Steeger RP. 2006. Does folic acid and zinc sulphate intervention affect endocrine parameters and sperm characteristics in men?. Intern J Androl 29: 339-345.

8. Fiser PS, Hansen C, Underhill H, Marcus GJ. 1991. New thermal stress test to assess the viability of cryopreserved boar sperm. Cryobiology 28: 454-459.

9. Gancarczyk M, Kuklinska M, Sadowska J, Strzezek J, Bilinska B. 2006. Aromatization and antioxidant capacity in the testis of seasonally breeding bank voles: effects of LH, PRL and IGF-I. Theriogenology 65: 1376-1391.

10. Garner DL, Thomas CA, Joerg HW, De Jarnette JM, Marshall CE. 1997. Fluorometric assessments of mitochondrial function and viability in cryopreserved bovine spermatozoa. Biol Reprod 57: 1401-1406.

11. Guerin P, El Mouatassim S, Menezo Y. 2001. Oxidative stress and protection against reactive oxygen species in the pre-implantation embryo and its surroundings. Hum Reprod Update 7: 175-189.

12. Hove SR, Dimick PS, Benton AW. 1985. Composition of freshly harvested and commercial royal jelly. J Apic Res 24: 52-61.

13. Kodai T, Umebayashi K, Nakatani T, Ishiyama K, Noda N. 2007. Compositions of royal jelly. II. Organic acid glycosides and sterols of the royal jelly of honeybees (Apis mellifera). Chem Pharm Bull 55: 1528-1531.
14. Krzyzosiak J, Molan P, Viswanath R. 1999. Measurement of bovine sperm velocities under true anaerobic and aerobic conditions. Anim Reprod Sci 55: 163-173.

15. Pontbriand D, Howard JG, Maximum MC, Stuart LD, Wildt DE. 1989. Effect of cryoprotective diluent and method of freeze-thawing on survival and acrosomal integrity of ram spermatozoa. Cryobiology 26: 341-354.

16. Saacke RG, White JM. 1972. Semen quality tests and their relationship to fertility. Proceedings of the 4th NAAB Technology Conference on Artificial Insemination Reproduction, Madison (USA), p. 22-27.

17. Shannon P, Curson B. 1972. Toxic effect and action of dead sperm on diluted bovine semen. J Dairy Sci 55: 614620.

18. Viswanath R, Shannon P. 1997. Do sperm cells age? A review of the physiological change in sperm during storage at ambient temperature. Reprod Fertil Dev 9: 321-331.

19. Watson PF, Martin IC. 1972. A comparison of changes in the acrosomes of frozen ram and bull spermatozoa. $J$ Reprod Fert 28: 99.

20. Wells ME, Awa OA. 1970. Neo technique for assessing acrosomal characteristics of spermatozoa. J Dairy Sci 53: 227.

21. Zemjanis R. 1977. Diagnostic and therapeutic techniques in animal reproduction, William \& Wilkins Co, Baltimore (USA), $242 \mathrm{p}$. 